\title{
The Effect of Culinary Knowledge and Culinary Experience on Local Culinary Attractiveness
}

\author{
Heri Setiawan ${ }^{1, *}$, Abd. Hamid ${ }^{1}$, Ummasyroh $^{1}$, Jusmawi Bustan ${ }^{1}$ \\ ${ }^{t}$ Business Administration Department, State Polytechnic of Sriwijaya, Palembang, Indonesia \\ "Corresponding author. Email: heri.setiawan@polsri.ac.id
}

\begin{abstract}
This study aimed to explore culinary knowledge and tourist culinary experiences in its relation to the local culinary attractiveness. The sampling technique used was purposive sampling with a sample of 297 respondents. Research data were analyzed using AMOS 22.0. Based on the overall research hypothesis tested, two hypotheses are rejected, namely the relationship between culinary engagement with local culinary attractiveness, and the relationship between culinary knowledge with local culinary attractiveness. Then, the accepted hypothesis is the relationship of culinary experience with local culinary attractiveness and the relationship between local culinary attractiveness and culinary tourism attractiveness. The results of this study contribute to knowledge, especially in the field of marketing local culinary tourism attractiveness. This research develops a culinary tourism attractiveness model based on the exploration of the uniqueness and distinctiveness of traditional culinary which is very closely related to the history and culture of the local people from the perspective of tourists.
\end{abstract}

Keywords: knowledge, experience, destination attraction, culinary tourism

\section{INTRODUCTION}

Local food today has become an inseparable part of tourism attractions and support in offering an indelible tourist undergoes to tourism. The increasingly dynamic competition level in the tourism business encourages tourism destination managers globally to integrate local food into one of the attractive tourism products and can be offered to tourists visiting a destination [1]. Previous research explains that local food that presents the culture and traditional lifestyle of a community can be used as a marketing strategy to promote tourism destinations and plays a crucial function in attracting tourists and can influence tourist behavior [2]. The study of local food role in tourism activities explains that local food attraction and the tourist basic needs in a visit to a destination will be able to determine tourist satisfaction. Tourists can choose various activities that they can do when visiting a destination, but tourists often cannot keep away from consuming of local food and drink in tourism destinations although the food offered is not yet known by tourists [3]. Foods cooked from various local ingredients are served by local restaurants in culinary tourism destinations as a medium to add tourist experience value and make a response to tourists' curiosity in local food [4]. Enthusiasm for local food is driven by various matters associated with environmental, ethical, health and the willingness to support healthy living behavior [5]. Besides, local food is considered healthier, fresher, tastier and more reliable because it is mixed from natural raw materials [6]. Local food is considered more natural, original, and conventional [7]. Tourists seeking sensations of local food palate and unforgettable dining impression rapidly grow [8].
Furthermore, assessment for genuineness and uniqueness, tourists can attract novelty of local food [7].

Empirical study of tourism attributes where one of them is local food has attracted many researchers in various parts of the world. Previous studies discussed about divergence strategy of local food for tourism destinations and building brand identity and marketing [9], [10], local food served by local restaurants [11], tourism product development [3], take pleasure in gastronomy tourism by tourist [12], regional development [13]. Study of culinary tourism explains that tourists who consume local culinary in a tourism destination have various motive [14] and plays an important role for the tourist experience [7]. Local food investigations can be very interesting scientific topics to explore more deeply because studies that explore the consumption of local food by tourists in tourism destinations are still scarce [15].

\section{LITERATURE REVIEW AND HYPOTHESES}

\subsection{Culinary Knowledge}

Collaboration among learning and tourist knowledge in excursion activities has been reviewed by various researchers. Tourists who visit gastronomic tourism destinations tend to integrate food and drink with local culinary experiences that encourage their willingness to learn how to cook [16]. Enjoying local food and beverage dishes is not only because of necessity but this activity plays an important role to gain knowledge of the cuisine, 
drinks, and the local community culture. The ability and high employee knowledge of local culinary in culinary tourism destinations is another attribute that has an imperative role in marketing culinary tourism [17]. Tourists can visit the culinary destination of tourism and learn the uniqueness of the local community wisdom [18]. Provision of local food is one of the strategies carried out by tourism destination managers to attract tourists visiting tourism destinations. Culinary tourism is offered as an option for tourists to enjoy something different and cannot be found in other tourism destinations. Local food can be used as a differentiator in a tourism marketing venture and has an important component in the sustainable tourism development process [19].

\subsection{Culinary Experience}

Local food has a decisive tourist attraction and is a consideration for tourist experiences, both tourists who are interested in traditional food and for tourists to be more relaxed in enjoying food [20]. Food cannot be separated from tourist activities and a necessity for individuals. However, attitudes and motivations to eat up and seek food experiences differ for each tourist. Some tourists have special concern in culinary experiences, which experiences of culinary are intended to utilize as driver to choices of destination [14]. Tourists can take a trip to culinary destinations to feel the local culinary practice. Culinary tourism can be conceived as an area of cultural tourism, where tourists can observe, participate, and understand people and other places through food and dining experiences [10], [21]. Other tourists consider experience to consume culinary is a crucial thing, however, do not determine the destination preference if evaluated derive from the commitment continuity to local cuisine. Local food provision in destinations of tourism tend to serve tourist's needs who visit and provide tourists who have the willingness to obtain profound lore of local cuisine and culture [11].

\subsection{Tourism Attraction}

Tourism destination managers must develop various supporting features to persuade tourists to visit and take pleasure in local food [22]. Tourism destination manager can perform various resources advantages of culinary tourism destination managed and differ from other destinations. Managers must provide various supporting facilities in culinary tourism destinations so that tourists can enjoy local food. Local cuisine has developed as the most notable attractiveness in destinations of culinary tourism [23]. Local food served with uniqueness and naturalness so that it can attract tourists to be keen on it. Local food uniqueness is related to the unique characteristics possessed by the people that exist in a destination and usually a non- separate part of the local culture. Tourists push to visit a destination of tourism by increased attractive local food and behalf of the strategies to increase tourism attractiveness [24]. Culinary tourism can offer local food taste sensation and provide a unique experience for tourists to enjoy local food [8].

\subsection{Culinary knowledge and culinary attractiveness}

Local food becomes a part of the superior model of a tourism destination [25]. Strategy that can be developed to create a tourism destination brand identity by improving the quality of local food [9]. Tourist knowledge about local culinary can be a driving force to participate in culinary tourism activities and provide unforgettable travel experiences in tourism destinations [26]. High level of tourist knowledge about local culinary in culinary tourism destinations will encourage tourists to be more satisfied with culinary-related experiences and will see local culinary as something more interesting [27]. Also, local culinary knowledge is believed as an influencing factor on tourist perceptions about culinary attractiveness [28] Tourist knowledge about gastronomy has a significant and positive relationship related to the gastronomy attractiveness [12]. Therefore, it could be hypothesized as follows.

H1: Tourist culinary knowledge influenced the perception of culinary attractiveness.

\subsection{Culinary experience and culinary attractiveness}

Tourist experiences related to certain tourism activities will sustainably support personal perceptions of an activity [29]. The tight level of tourist involvement with the local culinary will provide a more tourist experience with the culinary tourism. The tourist experience in enjoying local cuisine will increase tourist knowledge of the culinary consumed, then tourists have their culinary attractiveness assessment [30]. Local food and culture owned by the people in tourism destinations can attract tourists to experience unforgettable experiences and enjoy the local culture authenticity [31]. Research by [12] also states that the tourist experience enjoying gastronomic tourism is significantly and positively related to gastronomy attractiveness. Tourists who have good culinary experience will encourage them to give a higher score on culinary attractiveness. Therefore, it could be hypothesized as follows

$\mathrm{H} 2$ : Tourist culinary experience influenced the culinary attractiveness perception. 


\section{METHODS}

\subsection{Measurement Instrument}

The survey instrument was designed based on a scale developed in previous research to measure the construct of the conceptualized model. Culinary knowledge measuring using 5 indicators adjusted from the study of [29], [12]. Culinary experience measuring using 4 indicators adapted from the study of [29], [12]. Culinary attractiveness is measured by 5 indicators adjusted from [12].

\subsection{Population and Samples}

Instrument of research was developed according to the review of literature to collect empirical data for this research. The distribution of questionnaires was carried out for 3 weeks in June 2019 using purposive sampling. Respondents are domestic tourists who have visited culinary destinations in Palembang with a total of 297 people. Culinary tourism destinations in Palembang used in this research, such as in Jalan Jenderal Sudirman, Jalan Merdeka, Musi River, Pasar Kuto and Kampung Kapitan, which offer traditional food served with music and local cultural attractions.

\subsection{Analysis of Data}

Analysis of factor was employed to determine factor structures inherent with the research indicators formation. SPSS 23 and AMOS 22 software are used to analyze data. The first step was testing the measurement model and structural model. Confirmation factor analysis is performed to determine the measurement model, determine manifest variables that reflect the hypothesized latent variables. Then, the analysis of structural equation is used to find out the validity of construct, index of goodness, structural and measurement models and hypothesis testing.

\section{RESULTS}

\subsection{Instrument Validity and Reliability}

Cronbach $\alpha$ value was used as a guideline for measuring consistency and reliability for each variable. Alpha Cronbach's value for culinary knowledge construct, culinary experience, and culinary attractiveness showed significant internal consistency $0.791,0.810$ and 0.767 . Composite reliability (CR) score for culinary knowledge construct, culinary experience, and culinary attractiveness was 0.888 to 0.891 . The results of data analysis explained that the research instrument designed had a feasible of reliability because it was more aloft than a minimum score requirement [32].
Analysis of factor confirmatory used to determine standard of measurement model including testing validity of convergent and discriminant. The validity of convergent from measurement model proceeds was corroborated by reliability and extraction of average variance [32]. The reliability of item indicated the divergence of item underlying construct and t-value described the value of a significant standard loading ( $\mathrm{p}<0.01$ ) explaining that the item was reliable. Requirements for construct reliability value must be similar or above 0.7 and extraction of average variance, wherein the number of the variants size of construct have to over 0.5 [32].

The reliability of all research constructs was higher than the minimum score required and the average variance extraction of culinary knowledge, culinary experience, and culinary attraction was above 0.5. Measurement of item result indicated has an elevated of validity level and reliability. Then, the discriminant validity test was carried out to find out discrimination between constructs. The AVE method was used to determine the validity of discriminant between constructs which was indicated AVE from constructs higher than the correlation among constructs [33]. Table 3 described the significance of correlations between factors that have good reliability of discriminant.

Table 1 Result of reliability test

\begin{tabular}{|c|c|c|}
\hline Measures construct & Cronbach $\boldsymbol{\alpha}$ & $\begin{array}{c}\text { Composite } \\
\text { Reliability (CR) }\end{array}$ \\
\hline Culinary knowledge & 0.791 & 0.886 \\
\hline Culinary experience & 0.810 & 0.857 \\
\hline Culinary attractiveness & 0.767 & 0.980 \\
\hline
\end{tabular}

Table 2 Result of convergent validity test

\begin{tabular}{|c|c|c|c|c|}
\hline Construct & $\begin{array}{c}\text { Standardized } \\
\text { Regression }\end{array}$ & $\begin{array}{c}\text { Error of } \\
\text { estimate }\end{array}$ & C.R & AVE \\
\hline & 0.648 & 0.084 & 10.231 & \\
Culinary & 0.465 & 0.066 & 8.348 & \\
Knowledge & 0.817 & - & - & 0.610 \\
& 0.730 & 0.067 & 13.055 & \\
\hline & 0.718 & 0.080 & 12.885 & \\
Culinary & 0.652 & 0.060 & 10.982 & \\
Experience & 0.541 & 0.075 & 9.121 & 0.601 \\
& 0.843 & 0.083 & 13.775 & \\
\hline & 0.762 & - & - & \\
Culinary & 0.724 & - & - & \\
Attractiveness & 0.688 & 0.095 & 10.607 & \\
& 0.502 & 0.115 & 7.962 & 0.603 \\
& 0.712 & 0.100 & 9.420 & \\
& 0.733 & 0.102 & 11.076 & \\
\hline
\end{tabular}

\subsection{Structural model and hypotheses test}

Relationships test among constructs of conceptual model use method of estimation of maximum likelihood. Path coefficient value resulting from testing the structural model presented in table 4 . The analysis showed that all structural path estimates were significant $(\mathrm{p}=0.177)$, including the chi-square statistic $\left(\chi^{2}=29.92, \mathrm{df}=45\right),\left(\chi^{2 / \mathrm{df}}=0.664\right)$ 
less than three [34]. Then, other indexes related to the model suitability test were: $\mathrm{RMSEA}=0.025$; $\mathrm{CFI}=0.995$; AGFI $=0.943$; GFI $=0.974$; also supported feasibility of a structural model that showed that the structural path was consistent with the hypothesized relationship between latent constructs.

The critical ratio (CR) value can be used as a guideline for evaluating the significance of research hypotheses [34]. When the critical ratio (CR) was in the range -1.96 to 1.96 , the hypothesis would be rejected. Based on table 5 , culinary knowledge and culinary attractiveness had a significant and positive relationship $(\beta=0.455, \mathrm{CR}=4,292)$ with $\mathrm{p}$-value $=0,000<0.05$ so that it supported Hypothesis 1 . These findings explained that culinary knowledge was a significant predictor of culinary attractiveness. The results of structural analysis explained that culinary knowledge had a significant and positive influence on culinary attractiveness. This study supported the research of [12], [28], [35] who explained that the knowledge possessed by tourists about local culinary has a significant and positive influence on culinary attractiveness.

Table 3 Result of discriminant validity test

\begin{tabular}{|l|l|c|c|}
\hline \multicolumn{1}{|c|}{ AVE/R } & \multicolumn{1}{c|}{$\begin{array}{c}\text { Culinary } \\
\text { Knowledge }\end{array}$} & $\begin{array}{c}\text { Culinary } \\
\text { Experience }\end{array}$ & $\begin{array}{c}\text { Culinary } \\
\text { Attractiveness }\end{array}$ \\
\hline Culinary Knowledge & $\mathbf{. 6 1 0}$ & & \\
\hline Culinary Experience & .492 & $\mathbf{. 6 0 1}$ & \\
\hline $\begin{array}{l}\text { Culinary } \\
\text { Attractiveness }\end{array}$ & .549 & .532 & $\mathbf{. 6 0 3}$ \\
\hline
\end{tabular}

Table 4 Result of Structural Equation Model

\begin{tabular}{|l|c|c|c|c|}
\hline Hypothesis testing & $\begin{array}{c}\text { Path } \\
\text { estimate }\end{array}$ & $\begin{array}{c}\text { Critica } \\
\text { I Ratio }\end{array}$ & Sig. & Evidence \\
\hline $\begin{array}{l}\text { Culinary } \\
\text { attractiveness <--- } \\
\text { culinary knowledge }\end{array}$ & .455 & 4.292 & .000 & Supported \\
\hline $\begin{array}{l}\text { Culinary } \\
\text { attractiveness <--- } \\
\text { culinary experience }\end{array}$ & .239 & 2.247 & .025 & Supported \\
\hline
\end{tabular}

Culinary experience and culinary attractiveness had a significant and positive relationship with culinary attractiveness $(\beta=0.239, \mathrm{CR}=2,247)$ with $\mathrm{p}$-value $=0.025$ $<0.05$ so that it supported hypothesis 2 . These findings explained that culinary experience was also a significant predictor of culinary attractiveness. The results of structural analysis explained that culinary experience had a significant and positive influence on culinary attractiveness. This study supported the research of [12], [28], [36], [35] which explained that the tourist experience while enjoying local cuisine has a significant and positive influence on culinary attractiveness. The cooking skills performed by local restaurant managers in culinary tourism destinations can affect tourist experiences [28].

Based on the analysis result, it could be seen that the culinary knowledge possessed by tourists was significantly and positively related to culinary attractiveness. The better knowledge about local culinary owned by tourists would make tourists more interested in visiting culinary tourism destinations and enjoying local cuisine. Then, the tourist experience in enjoying local cuisine was significantly and positively related to culinary attractiveness. In-depth tourist experience in enjoying local food while tourists were in tourism destinations would make them more interested in visiting tourism destinations.

\section{CONCLUSION}

The study provided good appreciate of tourist experiences related to culinary tourism. It was important for culinary tourism managers to provide services to tourists so that it would provide a better experience. Therefore, to improve the tourist experience the culinary tourism managers must have focused more on service factors such as setting a better culinary tourism environment, improving employee performance in providing services and interaction quality with tourists. Culinary tourism managers could increase visual attractiveness by changing the layout and physical environment in tourism destinations so that it would increase beauty and comfort. The interaction quality between tourists and employees could also be improved so that it could increase the perception of the tourist experience values.

\section{REFERENCES}

[1] Robinson, R.N.S. and Getz, D. (2014). "Profiling potential food tourists: an Australian study", British Food Journal, 116(4), pp. 690-706.

[2] Henderson, J.C. (2014). "Food and culture: in search of a Singapore cuisine", British Food Journal, 116(6), pp. 905-917.

[3] Cohen, E., and Avieli, N. (2004). Food in tourism: Attraction and impediment. Annals of Tourism Research, 31(4), pp. 755-778.

[4] Pieniak, Z., Verbeke, W., Vanhonacker, F., Guerrero, L. and Hersleth, M. (2009). "Associations between traditional food consumption and motives for food choice in six European countries", Appetite, 53(1), pp. 101-108.

[5] Pearson, D., Henryks, J., Trott, A., Jones, P., Parker, G., Dumaresq, D. and Dyball, R. (2011). "Local food: understanding consumer motivations in innovative retail formats", British Food Journal, 113(7), pp. 886-899.

[6] Roininen, K., Arvola, A. and Lahteenmaki, L. (2006), "Exploring consumer perceptions of local food with two different qualitative techniques: 
laddering and word association", Food Quality and Preference, 17(1/2), pp. 20-30.

[7] Kauppinen-Räisänen, H., Gummerus, J. and Lehtola, K. (2013), "Remembered eating experiences described by the self, place, food, context and time", British Food Journal, 115(5), pp. 666-685.

[8] Gyimóthy, S. and Mykletun, R. (2009). "Scary food: commodifying culinary heritage as meal adventures in tourism", Journal of Vacation Marketing, 15(3), pp. 259-273.

[9] Okumus, F., Kock, G., Scantbury, M. and Okumus, B. (2013). "Using local cuisines when promoting small Caribbean island destinations", Journal of Travel and Tourism Marketing, 30(4), pp. 410-429.

[10] Lin, Y.C., Pearson, T. and Cai, L. (2011). "Food as a form of destination identity: a tourism destination brand perspective", Tourism and Hospitality Research, 11(1), pp. 30-48.

[11] Yurtseven, R., and Rich, O. (2011). "Local food in local menus: the case of Gokceada", Tourismos: An International Multidisciplinary Journal of Tourism, 6(2), pp. 263-275.

[12] Leong, L. Q., Ab Karim, S. M., Awang, W. K., and Abu Bakar, Z.A. (2017). An integrated structural model of gastronomy tourists' behavior", International Journal of Culture, Tourism and Hospitality Research, 11(4), pp. 573-592.

[13] Björk, P., and Kauppinen-Räisänen, H. (2016). Local food: a source for destination attraction. International Journal of Contemporary Hospitality Management, 28(1), pp.

[14] Tikkanen, I. (2007). "Maslow's hierarchy and food tourism in Finland: five cases", British Food Journal, 109(3), pp. 635-653

[15] Kim, Y. G., Eves, A., and Scarles, C. (2009). Building a model of local food consumption on trips and holidays: A grounded theory approach. International Journal of Hospitality Management, 28(3), pp. 423-431.

[16] Hjalager, A. M. (2003). What do tourists eat and why? Towards a sociology of gastronomy and tourism. In J. Collen \& G. Richards (Eds.). Gastronomy and tourism. (pp. 54-74). Schilde: Academie Voor de Streek gebonden Gastronomy.
[17] Smith, S., and Costello, C. (2009). Segmenting visitors to a culinary event: Motivations, travel behavior, and expenditures. Journal of Hospitality Marketing and Management, 18(1), pp. 44-67.

[18] Ignatov, E., and Smith, S. (2006). Segmenting Canadian culinary tourists. Current Issues in Tourism, 9(3), pp. 235.

[19] Sims (2009). Food, place and authenticity: local food, and the sustainable tourism experience. Journal of Sustainable Tourism. 17(3), pp. 321336.

[20] Henderson, J. C. (2009). Food tourism reviewed. British Food Journal, 111(4), pp. 317-326.

[21] Setiawan, H. (2018). Keterkaitan antara citra destinasi, persepsi nilai Pengalaman dan kepuasan wisatawan kuliner, MIX: Jurnal Ilmiah Manajemen, 8(3), pp. 523-540.

[22] López-Guzmán, T., and Sánchez-Cañizares, S. (2012). Culinary tourism in Córdoba (Spain). British Food Journal, 114(2), pp. 168-179.

[23] Galvez, P. C.S., Lopez-Guzman, T., Buiza, C.F., and Medina-Viruel, J.M. (2017).Gastronomy as an element of attraction in a tourist destination: the case of Lima, Peru. Journal of Ethnic Foods, 4, pp. 254-261.

[24] Hillel, D., Belhassen, Y. and Shani, A. (2013). "What makes a gastronomic destination attractive? Evidence from the Israeli Negev", Tourism Management, 36, pp. 200-209.

[25] Florek, M. and Conejo, F. (2007). "Export flagships in branding small developing countries: the cases of Costa Rica and Moldova", Place Branding and Public Diplomacy, 3(1), pp. 53-72.

[26] Charters, S. and Ali-Knight, J. (2002). "Who is the wine tourists?", Tourism Management, 23(3), pp. 311-319.

[27] Kivela, J. and Crotts, J. C. (2006). "Tourism and gastronomy: Gastronomy's influence on how tourists experience a destination", Journal of Hospitality and Tourism Research, 30(3), pp. 354377.

[28] Guan, J. and Jones, D. L. (2015). "The contribution of local cuisine to destination attractiveness: an analysis involving Chinese tourists' heterogeneous 
preferences", Asia Pacific Journal of Tourism Research, 20(4), pp. 416-434.

[29] Trauer, B. (2006). "Conceptualizing special interest tourism-Frameworks for analysis", Tourism Management, 27(2), pp. 183-200.

[30] Schiffman, L. and Kanuk, L., (2009), Consumer behavior, Prentice-Hall, New Jersey.

[31] Pesonen, P., Komppula, R., Kronenberg, C. and Peters, M. (2011). "Understanding the relationship between push and pull motivations in rural tourism”, Tourism Review, 66(3), pp. 32-49.

[32] Hair Jr, J.F., Hult, G.T.M., Ringle, C.M and Sarstedt, M. (2016). A Primer on Partial Least Squares Structural Equation Modeling (PLS-SEM) (Second Edi). Los Angeles: SAGE Publications, Inc.

[33] Wang, L.T., Tran, K.T. P., and Tran, T. V. 2017. Destination perceived quality, tourist satisfaction, and word-of-mouth, Tourism Review, 72(4), pp. $392-410$.

[34] Hair, J.-F. J., Black, W. C., Babin, B. J. and Anderson, R. E. (2014). Multivariate data analysis, ( $7^{\text {th }}$ ed.), Pearson Education Limited, USA.

[35] Ab. Karim, M. S., Chua, B. L. and Salleh, H. (2009). "Malaysia as a culinary tourism destination: International tourists' perspective", Journal of Tourism, Hospitality, and Culinary Arts, 1(2), pp. 63-78.

[36] Yun, D., Hennessey, S. M., and MacDonald, R. (2011). Understanding culinary tourists: Segmentations based on past culinary experiences and attitudes toward food-related behavior. 2011 International CHRIE Conference. Retrieved from http://scholarworks.umass.edu/refereed/ICHRIE_2 011. 